\title{
Otoliths sagittae of Merluccius hubbsi: an efficient tool for the differentiation of stocks in the Southwestern Atlantic
}

\author{
André Martins Vaz-dos-Santos ${ }^{1 *}$, Nayra Nicolau dos Santos-Cruz ${ }^{2}$, Daniele de Souza ${ }^{1}$, Aline \\ Giombelli-da-Silva ${ }^{1}$, Bárbara Gris ${ }^{1}$, Carmen Lúcia Del Bianco Rossi-Wongtschowski ${ }^{3}$
}

\author{
${ }^{1}$ Universidade Federal do Paraná \\ (Rua Pioneiro, 2153, 85.950-000, Palotina, PR, Brazil) \\ ${ }^{2}$ Secretaria de Educação/Faculdade ALFA \\ (Avenida Presidente Kennedy, 4285, 11.702-485, Praia Grande, SP, Brazil) \\ ${ }^{3}$ Instituto Oceanográfico da Universidade de São Paulo \\ (Praça do Oceanográfico, 191, 05508-900, São Paulo, SP, Brazil)
}

*Corresponding author: andrevaz@ufpr.br

The Argentine hake, Merluccius hubbsi Marini, 1933, occurs continuously in the Southwestern Atlantic between $21^{\circ} \mathrm{S}$ and $55^{\circ} \mathrm{S}$, from the shallow waters $(\sim 20-30 \mathrm{~m})$ of the continental shelf to the upper slope (commonly to $500-600 \mathrm{~m}$, but recorded until 785m) (COUSSEAU; PERROTTA, 2004; LLORIS et al., 2005). It is an important fishing resource shared among Brazil, Uruguay and Argentina, targeted by bottomtrawl fleets throughout its distribution area (LORENZO; DEFEO, 2015; VAZ-DOS-SANTOS; SCHWINGEL, 2015). Several studies have investigated the economic importance, biological, ecological and fishing aspects of $M$. hubbsi. The most recent contributions are on juvenile growth (BURATTI; SANTOS, 2010; LORENZO et al., 2011), foraging strategies (TEMPERONI et al., 2013; BELLEGGIA et al., 2014), systematics (DÍAZ-DE-ASTARLOA et al., 2011) and differences in reproductive aspects and larval development (BETTI et al., 2014; MACCHI et al., 2016). The majority of them came from the Argentina and none is related to use of otolith morphology and morphometry to ascertain geographic variation of the species.

The identification of stocks, defined as homogeneous population units for management purposes (BEGG; WALDMAN, 1999), is very important in the use and management of a fishing resource. The stocks of $M$. hubbsi throughout its distribution area have been defined based on differences in time and spawning area, concentrations of eggs, larvae and juveniles, growth and abundance (BEZZI et al., 2004; VAZ-DOS-SANTOS; SCHWINGEL, 2015). In Brazil, there are two hake stocks, the Southeastern, between $21^{\circ} \mathrm{S}-29^{\circ} \mathrm{S}$, and the Southern, between $29^{\circ} \mathrm{S}-34^{\circ} \mathrm{S}$, the latter shared with Uruguay and Argentina (VAZ-DOS-SANTOS et al., 2009). The conceptual border of these stocks is the parallel $29^{\circ} \mathrm{S}$, where there are transitional oceanographic

Submitted on: 08/Dec/2016

Approved on: 11/May/2017

http://dx.doi.org/10.1590/S1679-87592017143506503 features between the Southeastern and the Southern regions (CASTRO et al., 2006) and, additionally, this is also the border of FAO fishing areas 2.1 and 2.2 (FAO Major Fishing Areas, 2017). Other two stocks are defined in Uruguay and Argentina, the Bonaerense (between $34^{\circ} \mathrm{S}-41^{\circ} \mathrm{S}$ ), and the Patagonic $\left(41^{\circ} \mathrm{S}-55^{\circ} \mathrm{S}\right)$ (BEZZI et al., 2004).

Otoliths sagittae have been recognized as a promising tool for distinguishing stocks. The current methods for this include the analysis of the structure of rings (BROPHY, 2014; ROMOCURIEL et al., 2015; GOERTLER et al., 2016); elemental composition (CAMPANA et al., 2000; NIKLITSCHEK et al., 2010; AVIGLIANO; VOLPEDO, 2016); and morphology and morphometry (LEGUÁ et al., 2013; SADIGHZADEH et al., 2014). The results of analyses of ring formation and growth (BURATTI; SANTOS, 2010; LORENZO et al., 2011; VAZDOS-SANTOS; SCHWINGEL, 2015), linear morphometry and chemistry analyses (BEZZI et al., 2004) suggested that the sagittae of $M$. hubbsi may be used to ascertain variations among stocks.

The samples were obtained during surveys using bottom-trawl, from August-2001 to June-2002 (cf. HAIMOVICI et al., 2008), and from commercial landings in January and July-2004, between $21^{\circ} \mathrm{S}-34^{\circ} \mathrm{S}$. Specimens of $M$. hubbsi were measured (total length, $\mathrm{Lt}, \mathrm{mm}$ ) and otoliths sagittae were extracted, cleaned, dried and stored for ulterior analysis. The left otoliths were measured in terms of length (Lo), height (Ho), thickness (To), length and height of the sulcus acusticus (Lsa and Hsa), length of the posterior region (Lpr), area (A) and perimeter (P) of the otolith's outline (ROSSI-WONGTSCHOWSKI, 2015; LOMBARTE; TUSET, 2015). These measurements were used to calculate aspect ratios $(\mathrm{Lo} / \mathrm{Lt}, \mathrm{Ho} / \mathrm{Lo}, \mathrm{To} /$ Lo, Lsa/Lo, Lpr/Lo) and the shape indices commonly applied to otoliths: ellipticity, rectangularity, form factor, roundness and circularity (TUSET et al., 2003). The relative area of the sulcus acusticus (RAsa) was calculated 
using the equation RAsa=Lsa.Hsa/Lo.Ho. The effect of the differences in body lengths was eliminated from those indices (generally, aspect ratios + shape indices) by weighting them with the exponent $b$ of the function "Index" " $=a \mathrm{Lt}^{b}$ following LOMBARTE and LLEONART (1993). The regressions were adjusted by the non-linear least squares method (VAZ-DOS-SANTOS, 2015). The corrected values of the indices were used to analyze the geographic variation in four areas between $21^{\circ} \mathrm{S}-34^{\circ} \mathrm{S}$, defined in view of the oblique coastline and environmental features, based on CASTRO et al. (2006) and BRAGA and NIENCHESKI (2006). The area $\mathrm{A}\left(42^{\circ} \mathrm{W}-44^{\circ} \mathrm{W}\right)$ is related to the upwelling of Cape Frio region. The area $\mathrm{B}$ $\left(44^{\circ} \mathrm{W}-46^{\circ} \mathrm{W}\right)$ is associated to the sub superficial shelf break upwelling. The area $\mathrm{C}\left(46^{\circ} \mathrm{W}-48^{\circ} \mathrm{W}\right)$ receives the influence of the Paranaguá Estuarine Complex. The area $\mathrm{D}\left(50^{\circ} \mathrm{W}-52^{\circ} \mathrm{W}\right)$ is under influence of the PatosMirim Lagoon System and cold waters derived from the Malvinas/Falklands Current (Figure 1).

Three techniques were applied to evaluate the differences in the sagittae of $M$. hubbsi across the four areas, as follows. The values of each index were tested per area using the Kruskal-Wallis test ( $p<$ alpha $=0.05$ ), followed by a post-hoc Mann-Whitney test for $2 \times 2$ comparisons (ZAR, 2010). Principal component analysis (PCA) was applied to the set of transformed indices $[\log [\mathrm{x}+0.01)]$ (VALENTIN, 2012). A discriminant analysis (with Jackknife) was applied to the set of indices per area, tested through a PERMANOVA (ANDERSON et al., 2008; HAIR et al., 2009).

A total of 551 sagittae from specimens of $M$. hubbsi with total length between $48-597 \mathrm{~mm}$ were analyzed. The indices $\mathrm{Lo} / \mathrm{Lt}$, To/Lo, rectangularity, form factor, roundness and circularity did not show any variation per area (KruskalWallis test, $p>0.05$ in these cases, Table 1), presenting a similar pattern (values) throughout the whole area analyzed. On the other hand, the aspect ratios Ho/Lo, Lsa/Lo, Lpr/Lo, the ellipticity and the relative area of the sulcus acusticus (RAsa) showed significant variation among areas (KruskalWallis test, $p<0.05$ in these cases) (Table 1, Figure 2). These differences were due only to area $\mathrm{D}$ with respect to the others (post-hoc Mann Whitney test, $p<0.05$ ). PCA analysis resulted in $72 \%$ of explanation of the total variation of the indices by the first and the second components, due to the RAsa, Lsa/ Lo (eigenvector values of 0.84 and 0.41 , respectively, PC1) and $\mathrm{Lpr} / \mathrm{Lo}$ (eigenvector value of 0.91, PC2) (Figure 3A). The values of otolith indices of areas A, B and C overlapped while those from area $\mathrm{D}$ presented a differentiated pattern. The results of discriminant analysis also conducted to the longitude $\left({ }^{\circ} \mathrm{W}\right)$

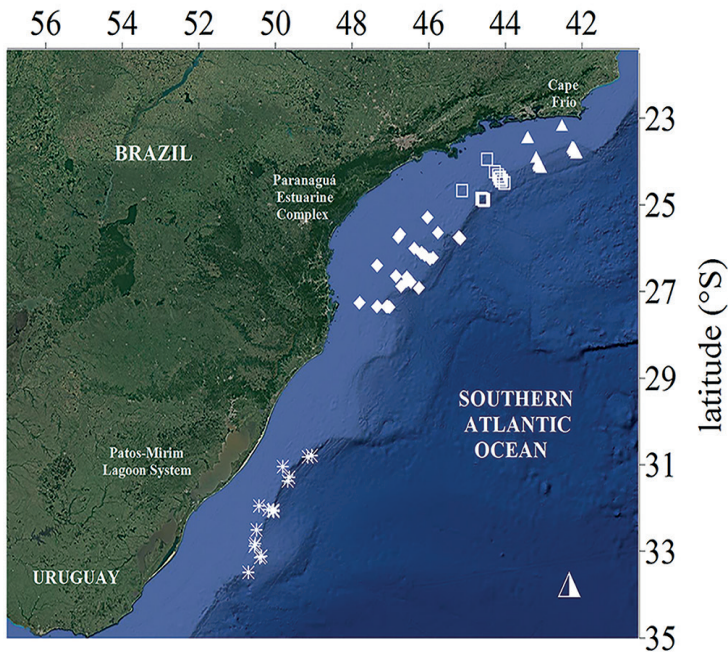

Figure 1. Sample sites from surveys using bottom-trawl during 2001 and 2002, also corresponding to the commercial catches of 2004 (symbols represent the groups used in the analysis: Area $\mathrm{A}=$ triangle, Area $\mathrm{B}=$ square, Area $\mathrm{C}=$ diamond, Area $\mathrm{D}=$ asterisk).

Table 1. Statistics $(\mathrm{H})$ and probability values ( $p$-value, in bold those statistically significant) of Kruskal-Wallis test applied to shape indices.

\begin{tabular}{lccccc}
\hline Index & $\mathrm{H}$ & $p$-value & Index & $\mathrm{H}$ & $p$-value \\
\hline Lo/Lt & 1.50 & 0.682 & Ellipticity & 9.66 & $\mathbf{0 . 0 2 2}$ \\
Ho/Lo & 10.26 & $\mathbf{0 . 0 1 6}$ & Rectangularity & 7.58 & 0.056 \\
To/Lo & 1.36 & 0.715 & Form Factor & 5.26 & 0.154 \\
Lsa/Lo & 48.91 & $<\mathbf{0 . 0 0 1}$ & Roundness & 1.59 & 0.662 \\
Lpr/Lo & 57.12 & $<\mathbf{0 . 0 0 1}$ & Circularity & 5.32 & 0.150 \\
& & & RAsa & 53.23 & $<\mathbf{0 . 0 0 1}$ \\
\hline
\end{tabular}

same diagnostic (Figure 3B), with overlapped values of areas $\mathrm{A}, \mathrm{B}$ and $\mathrm{C}$ and differentiation of area $\mathrm{D}$, reinforced by the PERMANOVA $(\mathrm{F}=24.6, p=0.001$ in the overall analysis and $p<0.001$ due to area $\mathrm{D}$ in the pairwise comparisons).

The indices Ho/Lo, Lsa/Lo, Lpr/Lo, ellipticity and RAsa were the best morphological and morphometric indicators differentiating between the sagittae of the two stocks. There are two morphotypes of sagittae in the area, one related to areas $\mathrm{A}+\mathrm{B}+\mathrm{C}$ and another one related to area D. The otoliths of the Argentine hake from the Southern stock (area D) are proportionally more elongated, and shorter (lower values of the Ho/Lo ratio and greater ellipticity), especially in the posterior region, which is slender (greatest Lrp/Lo values), with the sulcus acusticus proportionally more elongated (higher values of Lsa/Lo and RAsa) (Figure 4). 

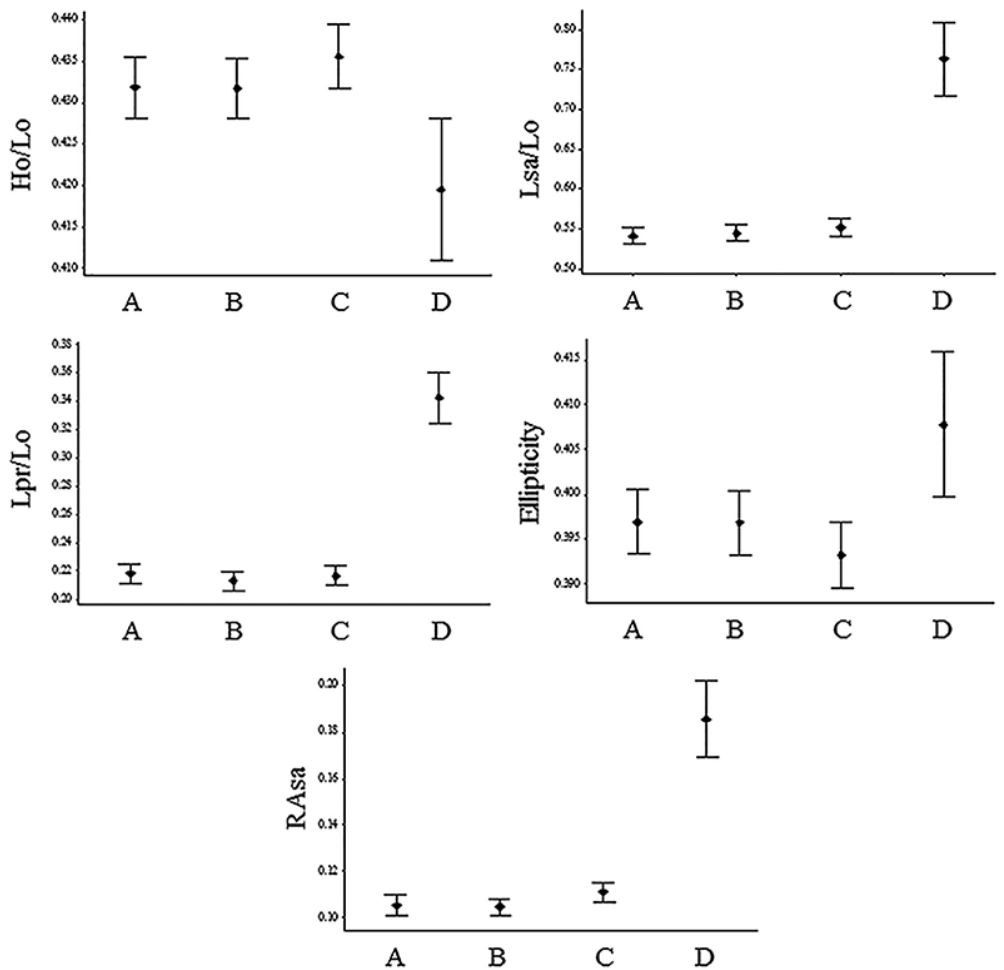

Figure 2. Average value and confidence interval (95\%) of the otolith shape indices by area (see the text for details).
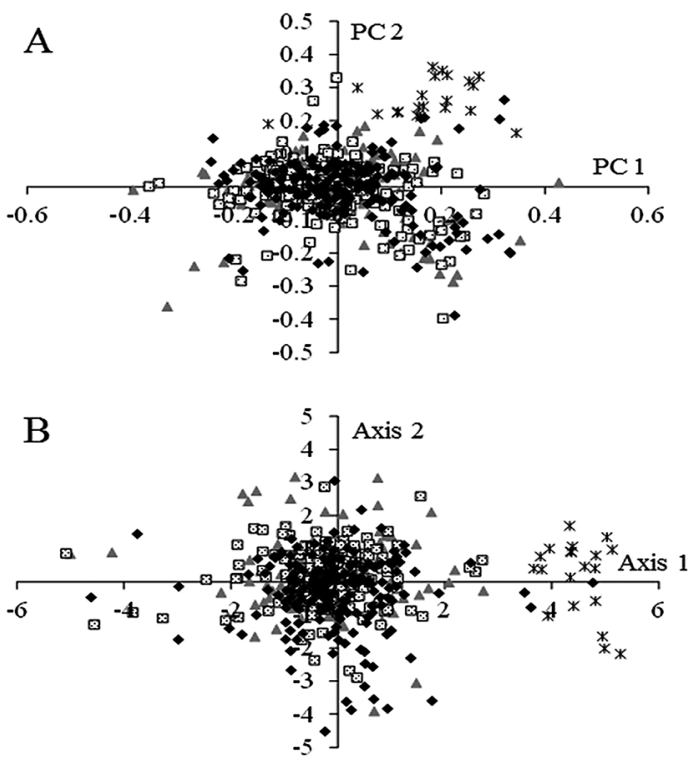

$\triangle$ Area A $\square$ Area B * Area C * Area D

Figure 3. Principal Component analysis ordination diagram based on the two first principal components (PC) (A) and Discriminant analysis diagram showing the axis 1 and 2 (B).

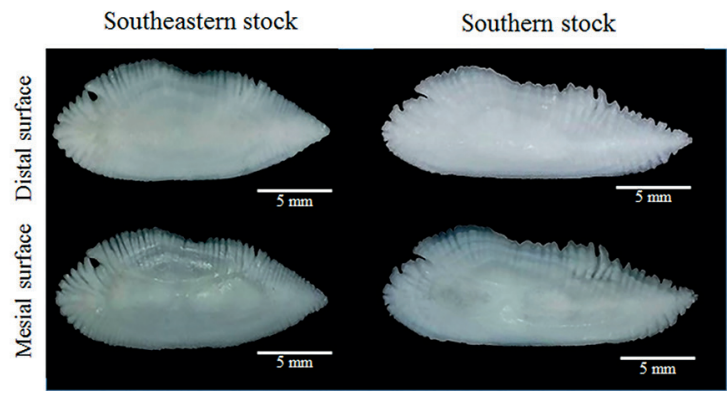

Figure 4. Sagittae otoliths of M. hubbsi from the Southeastern and the Southern stock.

The morphological and morphometric characteristics of the otoliths sagittae reinforce the current definition of the Brazilian stocks of M. hubbsi (VAZ-DOS-SANTOS; SCHWINGEL, 2015). Methodologically, the elimination of the size effect (LOMBARTE; LLEONART, 1993; CARVALHO et al., 2015) and the converging results of the quantitative methods applied (Kruskal-Wallis, PCA, Discriminant Analysis, PERMANOVA) reinforce the present diagnosis. Otoliths may reveal intraspecific 
variations when the appropriate methods are applied (BOLLES; BEGG, 2000; LEGUÁ et al., 2013; LOMBARTE; TUSET, 2015) and the morphology and morphometry of the sagittae of $M$. hubbsi in Brazil shall be added to the set of tools used to differentiate stocks (CADRIN et al., 2014). Although the samples were not continuous such the adults distribution is, it is reasonable to affirm that there is a unknown degree of mixture, once that reproduction and growth showed variability related to a southward gradient (VAZ-DOS-SANTOS; SCHWINGEL, 2015).

The differences found between the otoliths of the Southeastern and Southern stocks reflect the distinct environmental and trophic characteristics of the areas where the Argentinian hake grows (NORBIS et al., 1999; LORENZO et al., 2011). This also happens with other species of Merluccius that, likewise, are distributed throughout large areas (TORRES et al., 2000a; LOMBARTE et al., 2003; KEATING et al., 2014). On the other hand, the similarity in the otoliths of specimens belonging to the same stock strengthens the identity of the management unit, such that presented by the Southeastern stock in Brazil (current study) and the Patagonian stock in Argentina (TORRES et al., 2000b).

The Southeastern and Southern stocks of the Argentine hake need fishery management, which has been nonexistent in Brazil (VAZ-DOS-SANTOS; SCHWINGEL, 2015). In particular, the Southern stock, shared with Uruguay and Argentina, has not been jointly managed, due to political and economic reasons that date back to the extinction of the Comision Asesora Regional de Pesca para el Atlántico Sudoccidental (CARPAS), a FAO agency that was active until 1974 (VAZ-DOS-SANTOS et al., 2007). Biologically, the Southern stock shows specific features (HAIMOVICI et al., 1993; LORENZO et al., 2011) due to the environmental characteristics of the area, influenced by the Patos-Mirim Lagoon System and La Plata River outflow. This stock and the Bonaerense stock must be studied jointly by the three countries. The management of $M$. hubbsi only by Uruguay and Argentina through the Comisión Técnica Mixta del Frente Maritimo (VAZ-DOS-SANTOS et al., 2006; 2007; CTMFM, 2016) seems counter-intuitive in view of the vast knowledge about $M$. hubbsi, including the present results.

\section{ACKNOWLEDGEMENTS}

We are grateful to FAPESP for funding this research (Process 2007/04574-0) and for all people who helped us during the study of the Argentine hake. The first author thanks the CNPq for the Research Grant (Process 305403/2015-0)

\section{REFERENCES}

ANDERSON, M. J.; GORLEY, R. N.; CLARKE, K. R. PERMANOVA + for PRIMER: guide to software and statistical methods. Plymouth: PRIMER-E, 2008. 214 p.

AVIGLIANO, E.; VOLPEDO, A. V. A review of the application of otolith microchemistry toward the study of Latin American Fishes. Rev. Fish. Sci. Aq., v. 24, n. 4, p. 369-384, 2016.

BEGG, G. A.; WALDMAN, J. R. An holistic approach to fish stock identification. Fish. Res., v. 43, n. 1-3, p. 35-44, 1999.

BELLEGGIA, M.; FIGUEROA, D. E.; IRUSTA, G.; BREMEC, C. Spatio-temporal and ontogenetic changes in the diet of the Argentine hake Merluccius hubbsi. J. Mar. Biol. Assoc. U.K., v. 94 , n. 8, p. 1701-1710, 2014.

BETTI, P.; BROWN, D. R.; TEMPERONI, B.; MACHINANDIARENA, L.; EHRLICH, M. D. Larval growth of hake (Merluccius hubbsi) in the Patagonian shelf: Analysis of two reproductive seasons. Fish. Res., v. 160, p. 69-76, 2014.

BEZZI, S. I.; RENZI, M.; IRUSTA, G.; SANTOS, B.; TRINGALI, L. S.; EHRLICH, M. D.; SÁNCHEZ, F.; GARCÍA-DE-LA-ROSA, S. B.; SIMONAZZI, M.; CASTRUCCI, R. Caracterización biológica y pesquera de la merluza (Merluccius hubbsi). In: SÁNCHEZ, R. P.; BEZZI, S. I. (Eds.). El mar Argentino y sus recursos pesqueros. Tomo 4: los peces marinos de interes pesquero. Caracterización biológica y evaluación del estado de explotación. Mar del Plata: INIDEP, 2004. p. 157-205.

BOLLES, K. L.; BEGG, G. A. Distinction between silver hake (Merluccius bilinearis) stocks in US waters of the northwest Atlantic based on whole otolith morphometrics. Fish. Bull., v. 98, n. 3, p. 451-462, 2000.

BRAGA, E. S.; NIENCHESKI, L. F. H. Composição de massas de água e seus potenciais produtivos na área entre o Cabo de São Tomé (RJ) e o Chuí (RS). In: ROSSI-WONGTSCHOWSKI, C. L. D. B.; MADUREIRA, L. S. P. (Eds.). O ambiente oceanográfico da plataforma continental e do talude na região Sudeste-Sul do Brasil. São Paulo: EDUSP, 2006. p. 161-218.

BROPHY, D. Analysis of Growth Marks in Calcified Structures: Insights into Stock Structure and Migration Pathways. In: CADRIN, S. X.; KERR, L. A.; MARIANI, S. (Eds.). Stock Identification Methods. Applications in Fishery Science. Oxford: Elsevier, 2014. p. 141-170.

BURATTI, C. C.; SANTOS, B. A. Otolith microstructure and pelagic larval duration in two stocks of the Argentine hake, Merluccius hubbsi. Fish. Res., v. 106, n. 1, p. 2-7, 2010.

CADRIN, X. S.; KERR, L. A.; MARIANI, S. (Eds.). Stock Identification Methods. Applications in Fishery Science. $2^{\text {nd }}$ ed. Oxford: Elsevier, 2014. 588 p.

CAMPANA, S. E.; CHOUINARD, G. A.; HANSON, J. M.; FRÉCHET, A.; BRATTEY, J. Otolith elemental fingerprints as biological tracers of fish stocks. Fish. Res., v. 46, n. 1-3, p. $343-357,2000$

CARVALHO, B. M.; VAZ-DOS-SANTOS, A. M.; SPACH, H. L.; VOLPEDO, A. V. Ontogenetic development of the sagittal otolith of the anchovy, Anchoa tricolor, in a subtropical estuary. Sci. Mar., v. 79, n. 4, p. 409-418, 2015. 
CASTRO, B. M.; LORENZZETTI, J. A.; SILVEIRA, I. C. A.; MIRANDA, L. B. Estrutura termohalina e circulação na região entre o Cabo de São Tomé (RJ) e o Chuí (RS). In: ROSSI-WONGTSCHOWSKI, C. L. B.; MADUREIRA, L. S. P. (Eds.). O ambiente oceanográfico da plataforma continental e do talude na região Sudeste-Sul do Brasil. São Paulo: EDUSP, 2006. p. 11-120.

COUSSEAU, M. B.; PERROTTA, R. G. Peces marinos de Argentina: biologia, distribucion, pesca. Mar del Plata: INIDEP, 2004. $167 \mathrm{p}$.

CTMFM, 2016. Comisión Técnica Mixta del Frente Marítimo. Available: $<$ http://www.ctmfm.org/>. Accessed on: 2016 Oct 25

DÍAZ-DE-ASTARLOA, J. M.; BEZZI, S. I.; GONZÁLEZ CASTRO, M.; MABRAGAÑA, E.; HERNÁNDEZ, D.; DELPIANI, S. M.; FIGUEROA, D. E.; COUSSEAU, M. B.; DELI ANTONI, M. Y.; TRINGALI, L. Morphological, morphometric, meristic and osteological evidence for two species of hake (Actinopterygii: Gadiformes: Merluccius) in Argentinean waters. J. Fish. Biol., v. 78, n. 5, p. 1336-1358, 2011.

FOOD AND AGRICULTURE ORGANIZATION OF THE UNITED NATIONS. Fisheries and Aquaculture Department. Food: Major Fishing Areas. Atlantic, Southwest (Major Fishing Area 41). CWP Data Collection. Updated 1 October 2004. Available at: <http:// www.fao.org/fishery/area/Area41/en>. Accessed on: 2017 Feb 19.

GOERTLER, P. A. L.; SCHEUERELL, M. D.; SIMENSTAD, C. A.; BOTTOM, D. L. Estimating Common Growth Patterns in Juvenile Chinook Salmon (Oncorhynchus tshawytscha) from Diverse Genetic Stocks and a Large Spatial Extent. PloS $O N E$, v. 11, n. 10, p. e0162121, 2016.

HAIMOVICI, M.; MARTINS, A. S.; TEIXEIRA, E. L. R. Distribución, alimentación y observaciones sobre la reproducción de la merluza (Merluccius hubbsi) en el Sur de Brasil. Frente Marít., v. 14, p. 33-40, 1993.

HAIMOVICI, M.; ROSSI-WONGSTCHOWSKI, C. L. D. B.; BERNARDES, R. A.; FISCHER, L. G.; VOOREN, C. M.; SANTOS, R. A.; RODRIGUES, A. R. Prospecção pesqueira de espécies demersais com rede de arrasto-de-fundo na região Sudeste-Sul do Brasil. Sér. Doc. REVIZEE, Score Sul. São Paulo: Instituto Oceanográfico USP, 2008. 183 p.

HAIR JR., J. F.; BLACK, W. C.; BABIN, B. J.; ANDERSON, R. E.; TATHAM, R. L. Análise multivariada de dados. $6^{a}$ ed. Porto Alegre: Bookman, 2009. 688 p.

KEATING, J. P.; BROPHY, D.; OFFICER, R. A.; MULLINS, E. Otolith shape analysis of blue whiting suggests a complex stock structure at their spawing grouds in the Northeast Atlantic. Fish. Res., v. 157, p. 1-6, 2014.

LEGUÁ, J.; PLAZA, G.; PÉREZ, D.; ARKHIPKIN, A. Otolith shape analysis as a tool for stock identification of the southern blue whiting, Micromesistius australis/Análisis morfométrico de los otolitos como herramienta para la identificación de stock de la merluza de tres aletas, Micromesistius australis. Lat. Am. J. Aquat. Res., v. 41, n. 3, p. 479-489, 2013.

LLORIS, D.; MATALLANAS, J.; OLIVER, P. Hakes of the World (Family Merlucciidae). An annotated and illustrated catalogue of Hake species know to date. Rome: FAO, 2005. 57 p.

LOMBARTE, A.; LLEONART, J. Otolith size changes related with body growth, habitat depth and temperature. Environ. Biol. Fish., v. 37, n. 3, p. 297-306, 1993.
LOMBARTE, A.; TORRES, G. J.; MORALES-NIN, B. Specific Merluccius otolith growth patterns related to phylogenetics and environmental factors. J. Mar. Biol. Assoc. U.K., v. 83, n. 2, p. 277-281, 2003

LOMBARTE, A.; TUSET, V. Morfometria de otólitos. In: VOLPEDO, A. V.; VAZ-DOS-SANTOS, A. M. (Eds.). Métodos de estudo com otólitos: princípios e aplicações. Buenos Aires: CAFP-BA-PIESCI, 2015. p. 269-302.

LORENZO, M. I.; DEFEO, O. The biology and fishery hake (Merluccius hubbsi) in the Argentinean-Uruguayan Commom Fishing Zone of the Southwest Atlantic Ocean. In: ARANCIBIA, H. (Ed). Hakes: Biology and Exploitation. Oxford: Wiley Blackwell, 2015. p. 185-210.

LORENZO, M. I.; VAZ-DOS-SANTOS, A. M.; ROSSI-WONGTSCHOWSKI, C. L. D. B. Growth pattern of the young of the year Argentine hake Merluccius hubbsi Marini, 1933 (Gadiformes Merluccidae) along the Brazilian and Uruguayan coasts. Environ. Biol. Fish., v. 91, n. 2, p. 155-164, 2011.

MACCHI, G. J.; DIAZ, M. V.; LEONARDUZZI, E.; MILITELLI, M. I.; RODRIGUES, K. Skipped spawning in the Patagonian stock of Argentine hake (Merluccius hubbsi). Fish. Bull., v. 114, n. 4, p. 397-408, 2016.

NIKLITSCHEK, E. J.; SECOR, D. H.; TOLEDO, P.; LAFON, A.; GEORGE-NASCIMENTO, M. Segregation of SE Pacific and SW Atlantic southern blue whiting stocks: integrating evidence from complementary otolith microchemistry and parasite assemblage approaches. Environ. Biol. Fish., v. 89, n. 3, p. 399-413, 2010.

NORBIS, W.; LORENZO, M. I.; TORRES, G. J. Intra-annual growth variations of young-of-the-year hake (Merluccius hubbsi) of the Uruguayan continental shelf based on otolith analysis. Fish. Res., v. 44, n. 2, p. 129-137, 1999.

ROMO-CURIEL, A. E.; HERZKA, S. Z.; SOSA-NISHIZAKI, O.; SEPULVEDA, C. A.; AALBERS, S. A. Otolith-based growth estimates and insights into population structure of White Seabass, Atractoscion nobilis, off the Pacific coast of North America. Fish. Res., v. 161, p. 374-383, 2015.

ROSSI-WONGTSCHOWSKI, C. L. D. B. Morfologia de otólitos. In: VOLPEDO, A. V.; VAZ-DOS-SANTOS, A. M. (Eds.). Métodos de estudo com otólitos: principios e aplicações. Buenos Aires: CAFP-BA-PIESCI, 2015. p. 235-268.

SADIGHZADEH, Z.; VALINASSAB, T.; VOSUGI, G.; MOTALLEBI, A. A.; FATEMI, M. R.; LOMBARTE, A.; TUSET, V. M. Use of otolith shape for stock identification of John's snapper, Lutjanus johnii (Pisces: Lutjanidae), from the Persian Gulf and the Oman Sea. Fish. Res., v. 155, p. 59-63, 2014.

TEMPERONI, B.; VIÑAS, M. D.; BURATTI, C. C. Feeding strategy of juvenile (age-0+ year) Argentine hake Merluccius hubbsi in the Patagonian nursery ground. J. Fish. Biol., v. 83, n. 5, p. 1354-1370, 2013.

TORRES, G. J.; LOMBARTE, A.; MORALES-NIN, B. Variability of the sulcus acusticus in the sagittal otolith of the genus Merluccius (Merlucciidae). Fish. Res., v. 46, n. 1-3, p. 5-13, 2000a.

TORRES, G. J.; LOMBARTE, A.; MORALES-NIN, B. Sagittal otolith size and shape variability to identify geographical intraspecific differences in three species of the genus Merluccius. J. Mar. Biol. Assoc. U.K., v. 80, n. 2, p. 333-342, 2000 b. 
TUSET, V. M.; LOMBARTE, A.; GONZALEZ, J. A.; PERTUSA, J. F.; LORENTE, M. Comparative morphology of the sagittal otolith in Serranus spp. J. Fish. Biol., v. 63, p. 1491-1504, 2003.

VALENTIN, J. L. Ecologia numérica: uma introdução à análise multivariada de dados ecológicos. Rio de Janeiro: Interciência, 2012. $117 \mathrm{p}$.

VAZ-DOS-SANTOS, A. M. Métodos quantitativos aplicados ao estudo de otólitos. In: VOLPEDO, A. V.; VAZ-DOS-SANTOS, A. M. (Eds.). Métodos de estudo com otólitos: princípios e aplicações. Buenos Aires: CAFP-BA-PIESCI, 2015. p. 301-332.

VAZ-DOS-SANTOS, A. M.; ROSSI-WONGTSCHOWSKI, C. L. D. B.; FIGUEIREDO, J. L. Recursos pesqueiros compartilhados: bioecologia, manejo e aspectos aplicados no Brasil. Bol. Inst. Pesca, v. 33, n. 2, p. 273-292, 2007.
VAZ-DOS-SANTOS, A. M.; ROSSI-WONGTSCHOWSKI, C. L. D. B.; FIGUEIREDO, J. L. Recursos pesqueiros compartilhados entre Brasil, Uruguai e Argentina: a problemática de Merluccius hubbsi, Engraulis anchoita, Umbrina canosai e Illex argentinus. In: II Seminário de Gestão Socioambiental para o Desenvolvimento Sustentável da Aquicultura e da Pesca no Brasil. Rio de Janeiro: COPPE/UFRJ, 2006. p. 1-10.

VAZ-DOS-SANTOS, A. M.; ROSSI-WONGTSCHOWSKI, C. L. D. B.; FIGUEIREDO, J. L. Merluccius hubbsi (Teleostei: Merlucciidae): stock identification based on reproductive biology in the South-Southeast Brazilian region. Braz. J. Oceanogr., v. 57, n. 1, p. 17-31, 2009.

VAZ-DOS-SANTOS, A. M.; SCHWINGEL, P. R. Biology and fisheries of hake (Meluccius hubbsi) in Brazilian waters, Southwest Atlantic Ocean. In: ARANCIBIA, H. (Ed.). Hakes: Biology and Exploitation. Oxford: Wiley Blackwell, 2015. p. 211-233.

ZAR, J. H. Biostatistical analysis. $5^{\text {th }}$ ed. New Jersey: Pearson Prentice Hall, 2010. 944 p. 